\title{
RECONSTRUCTION OF PROSTITUTION LAW IN PERSPECTIVE OF RELIGIOUS NORMS AND RENEWAL OF CRIMINAL LAW
}

\author{
Noor Fajari Roziq ${ }^{1 *}$ \\ 1* Master of Law, Muhammadiyah University Malang, Indonesia, noor.fr@umm.ac.id (corresponding).
}

\begin{abstract}
Cases of prostitution as the subject of commercial sex workers (Pekerja Sex Komersial) and sex service users until now are free to undergo without the threat of punishment. Until now, there has been no rule that can punish prostitutes or prostitutes and their customers then there needs to be a legal reconstruction to achieve a responsive law then need to reform the law to achieve the law in the goal. This research aimed to know and understand the Construction of Prostitution Crimes in the Criminal Code, and The Penal Code Bill is associated with Religious Norms. And Know and understand the Construction of Formulation of Prostitution Crimes that are Ideal and in line with religious norms for Indonesian society, as for normative juridical research methods. The approach used in this writing is a statutory approach or (statute approach) and the analytical and conceptual approach analysis of legal concepts. The results show that it is necessary to explore the concept of philosophical, sociological, and juridical basic values that the state to have legal certainty in society in the Criminal War draft stage. So digging into the philosophical value of the $1^{\text {st }}$ Pancasila, The One Godhead (Ketuhanan yang Maha Esa), the five religions apply in Indonesia, including Islam, Christianity, Catholicism, Hindu, Buddha, and Confucian has asserted that the practice of prostitution is legally prohibited.
\end{abstract}

Keywords: Reconstruction; Law; Religion; Criminal

\section{INTRODUCTION}

Prostitution is a growing and growing form of criminality in society. The development of prostitution practices is increasing through the online base to facilitate access to offers to commercial sex services users. The practice of prostitution is factored into economic, educational, and social circumstances and a lack of knowledge of religious norms. In the practice of prostitution, a woman volunteers herself to work into a profession as a commercial sex worker who is in short (PSK) and assisted by pimps. The offer of prostitution practices is found in its activities through several social media applications, namely: Facebook, Twitter,
Tantan, and Mi Chat, to offer themselves to users of prostitution services (Palandi2, 2017).

The fact (das Sein) revealed that in the case of legally processed prostitution, practice is the online prostitution case by Robby Abbas (RA). RA was arrested in may 2015; suspect RA has 200 commercial sex workers ready to be offered to online prostitution services users. The rates of online prostitution services users vary to tens of millions, and RA benefits 20 percent from each transaction. RA has been running an online prostitution business for three years, using blackberry messenger (BBM) as a medium to inherit the community. While the police have owed RA files to the South Jakarta State Prosecutor's Office, Pimping RA was wearing Article 296-506 of the Civil Code on Decency with the threat of imprisonment one year four months long (Komang et al., 2018). 
In the example of the above event cases, women who work in prostitution practices are commercial sex workers, and those who use the service are free to undergo without the threat of punishment. If the practice of online prostitution is reviewed in the Criminal Code (Penal Code) perspective, in the criminal code of conduct on prostitution is not explained in its sense but related to the practice of prostitution is regulated in article 296 and article 506. Article 296 and 506 contained prostitution elements in the Criminal Code, only ensnare perpetrators who seek profit (pimping) and the provision of a place to facilitate lewd acts (Pimps) for Commercial Sex Workers and service users free from legal deterrents.

Users of the service cannot be legally using article 296 and article 506 unless the User of Prostitution service can be snared by law if the elements in article 284 of adultery but the weakness in article 284 is for those whose status is married and article 284 the is de complaints that then if there is no report of complaint from the person who harmed the husband or wife against adultery as in article 284 it is legal to do so then it can be concluded that the act of prostitution and its Commercial sex users are associated with the article that is tied to the status of marriage so that there is a legal void.

Review of Prostitution Practices outside the Human Code, namely Law No. 11 of 2008 on Information dan ElectronicTransaction (ITE) as to where in article 27 paragraph (1). As referred in article 27 , in paragraph 1 . The issue of online prostitution is not regulated in Set practice. So the parties involved in the prostitution practices Of commercial sex workers and service users are free from legal deterrents. The parties to the extent of providers, pimps, pimps related to sex workers and service users are untouchable by the law.

Discuss The Law No.44 of 2008 on pornography, addresses important matters in the practice of prostitution that can only criminalize Service Providers (Pimps), which contain photographs, illustrations, images, sounds, moving images, cartoons and animations. As well as similar messages through various forms of media, which violate the norms of decency in society. Looking at the rules governing character has not addressed the issue, meaning there is the rule of law on decency but not enough to criminalize sex workers and prostitution services users.

As with the trafficking crime law number 21 of 2007 as it must contain elements of people trafficking that conducts recruitment, transport, shelter, delivery, transfer or acceptance of a person with threats of violence, use of violence, kidnapping, arrest, forgery, fraud, abuse of power or vulnerable position of debt entanglement or giving payment or use benefit to obtain consent from the person in control of the other person either committed within the country or between countries to exploit or result in the person being exploited but in the act of criminal activity of the person's struggle in the case of prostitution that can be snared by law is the person who trades the person by using the recruitment of persons, transport of persons, person shelter, delivery of persons, transfer of persons, or acceptance of a person who can be threatened with violence, use of violence, kidnapping, arrest, forgery, fraud, and abuse of power.

From some regulations both the law, in general, the criminal code and specifically the law outside the criminal code relating to the practice of prostitution that the financier only against pimps or pimps in this case regulations related to prostitution practices are experiencing a legal void so as not to reflect the sense of fairness in the result of discrimination in its resolve.

Online prostitution in victims and perpetrators (Suzanalisa, Darmo, \& Alamsyah, 2019). In this case, both in general criminal law and special regulation of Criminal law that does not currently provide legal certainty and justice of the parties involved in the practice of prostitution Online.

Therefore, it is necessary (das sollen) government law State, in this case, the makers of the establishment of regulations per law or legislature need to dig up regulations following the state's philosophical nation. The government needs to dig up a number of its regulations or legal sources so that in those regulations, there are strict sanctions provisions and can be imposed and make One of the instruments to regulate people's lives. Regulatory formation per because the practice of prostitution is an act that deviates from religious norms, decency, and decency in society, the authorized government needs to construct to create a draft law in the formulation of criminalization policy against prostitution and accountability of prostitutes and users for preventive efforts or prevent the onset of prostitution practices both online and offline to achieve discipline, security and legal certainty as well as for the cause of the current criminal code philosophically, sociological and worthy of specifically formulated acts of prostitution in the regulation of the draft criminal code and explore the values that live in the middle of society.

To realize based on the perspective of the value of philosophical Godhead (Religious Norms) for the development of national law or the renewal of criminal 
law in Indonesia then by digging into the value of norm values as well as those sourced from the philosophy of the nation (Pancasila) who live in the community to obtain justice without discrimination, legal certainty and Benefit (Dwiyana Achmad Hartanto, SH, SHI, 2015).

Therefore, based on the above statement, the author's background to choose the title of the study: Reconstruction against the Act of Prostitution Perspective renewal of criminal law. The study tried to answer concerns related to the construction of prostitution crimes in the penal code. The bill of penal code is associated with religious norms; and how the structure of the formulation of prostitution crimes is ideal and under religious norms for Indonesia's people.

\section{RESEARCH METHODS}

The research method used in this writing is a normative juridical research method (Peter Mahmud Marzuki, 2014). The approach used in this writing is a statutory approach or (statute approach) and (analytical and conceptual approach) legal concept analysis approach (ZA Amiruddin, 2004).

The legal materials used in this study are obtained by conducting library research studies. The data analysis in this study was conducted qualitatively, namely the selection of theories - theories, principles, norms, doctrines, and articles in the law - the data analyzed qualitatively will be put forward in a systematic description explaining the relationship between types of data.

\section{RESULTS AND DISCUSSIONS}

Construction of Prostitution Crimes in the Penal Code and Penal Code Bill Din 2015 with Religious Norms

Reconstruction is to rebuild Indonesia's criminal justice system related to Legal reform and Legal development in the formulation of system development and legal renewal (Syafiq, 2014). The legal system consists of Legal culture, a legal substance, and a universal legal structure: :

1. Substantive development of criminal law materially penal code and direction outside the Penal Code, Formal Criminal Law ( KUHAP) and Criminal Execution Law;

2. The development of structures includes, among other things, the arrangement of institutions, the system of which Yemen and the supporting infrastructure mechanisms of the criminal justice system

3. Criminal law culture development needs to be noticed in one's in-person awareness, behavior, Knowledge education, and science (Enny, 2015).

Prostitution is an etymological sense that is derived from the Latin language; namely, prostitutes are peddling itself to commit immorality (adultery), peddling himself to do immorality Fornication and Intercharection. In the terminology of prostitution, according to KBBI, is: the word "lacur" which means poor, wretched, unlucky, failing or bad practice Prostitutes are prostitutes who prostitute, bitches, deaf women. Prostitution is about selling yourself as a prostitute, a brothel. The practice of prostitution as a sexual practice is done for a moment that can be done with anyone to get a reward in the form of money. The practice of prostitution deals freely and has emotionless sex, without the love that men do with commercial sex workers.

The development of prostitution workers currently uses the internet in carrying out their activities that more securely from officer raids, previously in the practice of prostitution conducting its activities directly on the streets and not looking safe, thus the online base electronic media is quite very easy to use in its activities. As for para parties involved in the practice of prostitution is (Anindia, 2019).:

1. Pimp is a person who benefits as a livelihood from commercial sex workers and provides a place to perform acts of inter mentation;

2. Commercial Sex Workers (PSK) are women who peddle themselves with service users.

3. Users of the Service are the one who buys commercial sex workers for sex.

Analysis of The Criminal Practice of Prostitution, in review from the Criminal Code's perspective and outside the Criminal Code. The analysis of the criminal practice of prostitution in the wise book of criminal law is: Based on article 296, article 506, and article 284 in the Penal Code.

As in article 296 Reads Whoever intentionally (Subjectively) causes or facilitates obscene acts by others with others, and makes a search or habit (Objective) threatened with a criminal one year four months and a fine of fifteen thousand rupiahs. Article 506 reads whoever benefits from an obscene act with a woman and makes a search threatened with imprisonment for one year and Article 284 paragraph 1. Threatened with a maximum prison sentence of nine 
months 1.a. a married man commits an overspill when it is known that article $27 \mathrm{BW}$ applies to him; 1.b. A married woman who has done the same. 2. a. A man who participated in the act, when it was known that the guilty had married. 2.b. A married man who participated in the act, when he knows it Nahwa who is also wrongly married and article $27 \mathrm{BW}$ applies to him. In paragraph 2 , there is no prosecution but on the tainted husband/wife's complaint, and when for them applies on $27 \mathrm{BW}$, within three months of the request for divorce or moving a table or bed for that reason.

The Author's Analysis that commercial sex workers and their services if reviewed in article 296 and article 506 on the crime of emergency that subjective or objective elements in the explanation are not fulfilled as perpetrators of the crime of case sanctions or legal threats are pimps and/or pimps who, as they take advantage of commercial sex workers, can be concluded in section 296 and section 506, and have the weakness that prostitution only threatens the Tout, pimp or pimp, non-prostitutes, and PSK service users.

The article 284 has the weakness of service users can be threatened criminal if it is known that prostitution under section 284 of commercial sex workers and service users can marriage be criminally threatened if they are found to be commercial sex workers, and users of the service unite in marriage and can be reported with their complaints of adultery.

So the national law is worthy of revision and tracing the source of the law and digging into the norms, and living in the community to realize the purpose of the law that meets the legal mind (ius constitudeum) in the middle of society. The analysis of regulations on the prosthesis, specifically outside the Statute Book of Criminal Law, is: The review of the law-law no. 11 of 2008 on information and electronic transactions article 27 paragraph 1 jo article 45 elements in the article related to the issue of prostitution has not solved the problem of prostitution practice, which is then snared by the law only on subjects who knowingly without the right to deliberately disseminate immoral photos to others without the knowledge of the owner of the photo in practice which is then ensured by the law but rather the person who knows the pimp. Therefore, there needs to be a renewal of criminal law in order to have legal certainty and benefit for the community because the practice of prostitution is a disease in society.

A review of law no. 44 of 2008 on graffiti porn in article 30 junco article 4 paragraph 1 which reads "Everyone is prohibited from producing, making, multiplying, doubling, disseminating, broadcasting, importing, exporting, offering, trading, renting, or providing pornography that explicitly contains: a. percent, including deviant religion; b. sexual violence; c. masturbation or masturbation; d. nudity or an impressive display of nudity; e. genitals; or f. child pornography.

Based on the author's analysis of the law's explanation, only gives legal sanctions if the elements of the dissemination of sketch drawings or videos are charged with decency. If in the perspective of prostitution practices based on the author's analysis that in this case is not covered from the problem of prostitution practices as in the article does not ensnare prostitutes or sex service users, then there needs to be a renewal of the law to provide a certainty law (Herman, 2019).

According to law 21 of 2007 on The Criminal Offences of People In such sections in prostitution cases that can be snared by law is the person who tradespeople by using, hiring, transporting, sheltering, sending, transferring, or receiving a person with threats of violence, use of force, kidnapping, kidnapping, arrest, forgery, fraud, abuse of power.

Based on the author's analysis that in the law, the practice of prostitution is imposed sanctions if met if proven to employ violence and sex workers and users in the criminal law of trafficking the person are not covered so that the PSK and Service Users do not impose sanctions under those laws.

The practice of prostitution in the Draft Law revised criminal law in 2019 is included in section four of article 417 of the adultery section 417 paragraph 1, which reads: Anyone who commits life together as a husband and wife outside marriage is sentenced to a maximum prison sentence of 6 (six) months or the maximum penalty of category II. Convicted of adultery with a maximum prison sentence of 12 years In paragraph 1, men and women who are each not bound by a legal marriage commit intercourse.

Based on the author's analysis, this article has a weakness. There is the Hole of the complaint, as in paragraph 2, which reads no prosecution except for complaints of husband, wife, parents, or children. That chapter $\mathrm{xV}$ on the criminal offense of decency in the fourth section on adultery has a weakness and multi interpretation that as long as it is in the practice of prostitution, no one complains then cannot be put criminally. The Hole complaint is restricted only to the husband or wife, parents, and children (Primary, 2017). Analysis of Prostitution Crimes perspective of legally recognized Religious Norms in Indonesia there are:

\section{Islam}


(QS Al-Isra' 17: 32)

"And do not approach adultery; indeed, adultery is an abomination. And a bad way."

(QS An-Nur 24 : 2)

"Fornicating women and adulterous men, then chasten every one of them a hundred times and do not have mercy on them preventing you from living the religion of Allah, if you) believe in Allah and the Hereafter, and let their punishment be witnessed by a group of believers (Primary, 2017).

\section{Hinduism and Buddhism}

Hinduism sees in the act of prostitution also strictly forbidden, the person who commits adultery will be put in hell named taptasurmi, in buddhism knows the rule of dasila namely ten prohibitions that must be known by buddhists of the bhiksu and pancasila five prohibitions that should be shunned by buddhists from the laypeople one of which is related to adultery.

3. Khonghucu religion (Confucius)

Prohibiting intermarital interlocking is forbidden to be done by anyone as set forth in si Shu / Book of Bing Cu Men Zi VII: 17 .1.

\section{Christianity and Catholicism}

Al-Corinthians 6: 9-10 that adultery is called a despicable deed, for which the perpetrator cannot inherit the kingdom of God (Primary, 2017).

Based on the analysis of the authors, can be concluded from 4 religious norms recognized that in the practice of prostitution is related to the legitimate religious norms in Indonesia that with the belief of the rules in the religion is perfect than the prevailing national law in this case that in the rule of religious norms does not impose restrictions or differences in adultery that was expressly bound both in marriage and non-marriage in acts categorized as adultery are explicitly prohibited and will be severely sanctioned based on the rules of religious norms.

Overall regulations relating to prostitution crimes both in general in the Penal Code and specifically outside the Penal Code and the Draft Penal Code, the author stipulates that it is not by the Principles in the establishment of good legislation because it is not based on the source of the regulation stipulated in Pancasila in this case, please 1 The almighty Godhead. Thus the applicable law does not cover all prostitutes only to the extent that pimps and pimps that in the ideal rule-making then need to dig based on the foundation of philosophy's, sociological foundation, juridical foundation and adjust to digging into the principles in the establishment of legislation - good legislation to realize the legal ideal in renewal or development of criminal law during society so that the measure of the achievement of the law of justice certainty and benefit.

\section{Construction of The Formulation of Prostitution Crimes, that are Ideal and under religious norms for Indonesian society.}

Legal construction is a strategic regulatory arrangement in the implementation of Legal reform in the community's mind. So in the matter of prostitution practices that are very troubling for the public to graft the legal subjects of PSK and Users of PSK services that need to be snared by the law then there needs to be a regulation on the establishment of legislation implemented in a definite way and method, standard, and standard that binds all institutions authorized to make legislation.

The legislator must come up with an ideal legal order and a rule order that must be based on the nation's morals in which the law is made or drafted, grows, and develops. The nation's morals make a guide to the principles of the law on which the rule of law is founded - good legislation by referring to philosophical foundations, sociological foundations, and juridical foundations..

As for the foundation of philosophy, sociological foundations, other juridical foundations are

1. Philosophical foundation: Legal reform of criminal law must be passed immediately and must be based on national objectives and those aspired to by an independent and sovereign nation. The practice of prostitution in the normative aspects of juridical is not under the development of the times that it is known still in dutch heritage products and needs to be adjusted in other words the renewal of criminal law and digging into the value of the Philosophical value of the country.

2. Sociological foundation: The practice of prostitution is factored into economic, social, and religious circumstances that are very lacking in knowledge so that the increasing practice of localization of prostitution in the country both in terms of artists and ordinary people, in this case, that needs to be taken seriously by legislators to enforce the substitution related to the practice of prostitution and collect data - objective data to interfere with or preventative efforts so that the 
establishment of a security and comfort in life in the community.

3. The basis of juridical: The act of prostitution in regulation either in general or specifically that applies at this time relating to the norms of decency, Europeanism and others are no longer by the norm norms that exist in the community in this regard in need for an ideal legal reform in society. Thus the philosophical, sociological, and juridical basis is above the consideration or reason for the need for the newly formed National Criminal Code to take into account:

1. Awareness and legal minds are based on the values of norm religion and Pancasila.

2. In need of law, it is necessary to pay attention to the state and the public with empirical fact data on the issue of national criminal law.

3. Existing regulations will impact substitutions or materials to be regulated (Primary, 2017).

Pancasila, which is the source of all legal sources and is the main in the establishment of legislation legislation expressly in article 2 of law - law number 10 of 2004 that mentions Pancasila is the source of all legal sources.

The national law is a law or legislation based on the Filososif of the Republic of Indonesia, namely Pancasila and the Constitution of the NRI 1945.

According to Barda Nawawi Arief, if the national legal system is seen as a legal substance, then the national legal system is the Pancasila legal system. The national legal system must be oriented towards three pillars:

1. Value-oriented- Godhead (Religiosity).

2. Value-oriented- Humanist.

3. Values-oriented-Social (nationalistic, democratic, social justice).

Bernard Arief Sidharta argued that the national legal order should contain six features;

1. National and archipelago insight;

2. Able to accommodate the legal awareness of local ethnic groups and religious beliefs;

3. As far as written and uncodified as possible;

4. The rationality that includes efficiency rationality, the rationality of fairness, the rationality of rules, and rationality of values;
5. Procedural rules that ensure transparency, which allow the rational review of the decision-making process by the government;

6. Responsive to developing people's aspirations and expectations (Achmad Irwan Hamzah, Mukhidin, 2018).

Based on Rudol Stammler, the law's mind is as the construction of thought, which is the obligation that leads the law to justice, certainty, and benefit.

According to Gustav Radbruch Argues that ius constitudeum not only serves as a regulative indicator, which tests whether positive law is fair or not but at the same time serves as a constitutive basis that determines that without a legal mind, the law will lose its meaning as the law of tan as the desired ideal of society (Rosadi, 2012).

So in establishing the ideal legislation in formulating in the criminal practice of prostitution should be considered the principles of the establishment of legislation which includes:

1. Clarity of objectives: that the establishment of regulation must have a clear goal to achieve the indicators

2. the authorized institution must make institutions or appropriate forming officials; any type of law, if it is not known that the official or the person charged in establishing this type of regulation, then the legal consequences can be canceled and or null and void for the sake of the law.

3. Conformity between type, hierarchy, and content material; in the establishment of regulations should pay attention to the appropriate material content, types, and hierarchy of regulations

4. Enforceable: each regulation must consider the regulatory effectivity of regulation in the community, both philosophically, sociologically, and judicially.

5. Utilization and success: every regulation is made indeed in the circumstances needed to be useful in wading into your community life, nationality, and country.

6. Clarity formula: each existing legal process meets the technicalities of the system, preparation, legal language, and choice of words.

7. Openness means that in an effort to shape regulation, openness must be done from the planning stage to the determination. 
In the act of prostitution practice from the prevailing regulatory aspects which is as an act of criminal decency in the Criminal Code that given article 296 and article 506 of the Criminal Code and regulations outside the Criminal Code relating to decency in the issue of prostitution has weaknesses in terms of legal subjects namely commercial sex service users and commercial sex workers are not included in the Criminal Code and outside the Criminal Code as the subject of the law of criminal acts of decency so that there is a legal void.

So in the current phase of the Draft Criminal Code, which is in the revised stage of discussion in the legislative state that the establishment of regulation in the criminal act of decency, especially the issue of prostitution crimes Need to explore the concept of philosophical, sociologically and fundamental values that the state to have legal certainty in society. So in order to establish an ideal regulation in the concept of criminalization of prostitution in Indonesia, it is necessary to dig into the religious norms contained in the philosophy of the country, namely Pancasila, which is contained in the $1^{\text {st }}$ Sila. Catholicism, which reads The Supreme Leader of Esa, that the five religions that apply in Indonesia, including Islam, Christianity, Catholicism, Hinduism, and Confucianism, have asserted that prostitution is legally haram.

The formulation of prostitution practice norms offers formulation in criminal decency to the legislature authorized against the renewal of criminal law or the development of criminal law that is just and has certainty and benefit an I with the mind of the law. As for the author's offer in the formulation of the ideal criminal offense against PSK and service users. As for the offer of the author in the formulation of the criminal act of err.

Ideal formulation of criminal decency crimes on Users of sex services commercial Article

(1) Any person who invites, summons, orders or rents through the media electronically and or directly to commit an obscene act and or sexual intercourse is commercially threatened with a maximum penalty of 1 (one) year or a category II fine

Ideal Formulation of Commercial Sex Workers.. Article

(1) Any person who commits an Intercourse and or lewd act with his consent to obtain or receive payment through electronic transactions and or is directly threatened with a criminal maximum of 1 (one year) and or a category II fine
The reasons the authors offered draft regulatory reconstructions related to the criminal acts of prostitution are:

1. The law of law - a criminal code that restricts the products of dutch colonies, has a deterrent effect on pimps and pimps in decency crimes.

2. Special criminal regulations - pornography laws, laws - and laws - allow people who have the right to snare and or effect it on commercial sex workers and commercial sex service users.

3. As point 1 and 2 , the applicable regulations do not suit the community's needs or that of the community to deter commercial sex workers and users of commercial sex services.

\section{CONCLUSION}

The establishment of regulation in the criminal act of decency, especially prostitution crimes, needs to explore the concept of values - the fundamental philosophical, sociological, and juridical values that the state to have legal certainty in society. So digging into the philosophical value of Pancasila the $1^{\text {st }}$ sila One Godhead that the five religions that apply in Indonesia, including Islam, Christianity - Catholicism, Hinduism Buddhism, and Confucianism, have asserted that the practice of prostitution is haram.

\section{BIBLIOGRAPHY}

Achmad Irwan Hamzah, Mukhidin, D. P. R. (2018).

Development of national law as the implementation of national goals. Joint Proceedings_U 2018, 1(3), 978-979.

Anindia. (2019). Criminal Law Policy in efforts to combat prostitution as a renewal of criminal law. Indonesian Journal of LegalDevelopment, 1830 .

Dwiyana Achmad Hartanto. (2015). Tackling Prostitution Online Perspective Of Criminal Law Reform In Indonesia And Islamic Criminal Law Dwiyana Achmad Hartanto, SH, SHI, MH. Proceedings of the National Seminar on the Rise of Technology, 53-64.

Enny. (2015). Draft Academic Text of the Criminal Law Bill..

Herman. (2019). Setting And Solving Online Prostitution Crimes According to Positive Law. 
Jurisprudentie : Department of Law Faculty of Sharia AndLaw, 4(2), 130.

Komang, N., Gendis, A., Subawa, M., Specialty, P., Criminal, H., Hukum, F., \& Udayana, U. (2018). What Is The Best Way To Get A Good Night's Work? Criminal Liability Users Of Online Prostitution Services According To Positive Laws In Indonesia, 07(04), 1-15.

Palandi, A. B. (2017). Criminal LIAbility for online Prostitution service Providers is Reviewed from law no. 11 of 2008 juncto Law No. 19 of 2016 on Electronic Information And Transactions, VI(1), 141-149.

Peter Mahmud Marzuki. (2014). Legal Research. Jakarta: Kencana Prenada Media Group.

Primary, S. S. B. and M. F. W. (2017). Responsibility for Prostitution through Online Media. EJurnal.Unisda:Responsibility of Perpetrators of Prostitution Crimes through Online Media, 1(1), 1-13.

Rosadi, O. (2012). The law of nature, pancasila and the principle of law in the establishment of laws in Indonesia. Id.Scribd. VOL10, 282-290.

Suzanalisa, S., Darmo, A. B., \& Alamsyah, B. (2019). Juridical Study On The Determination Of Online Prostitution Commercial Sex Workers As Victims Of People Trafficking Crimes According To Indonesian Criminal Law (Case Study in Jambi Regional Police Jurisdiction). Legality: Legal Journal, 11(2), 288. https://doi.org/10.33087/legalitas.v11i2.180

Shayafiq, A. (2014). Reconstruction of Funding in Islamic Criminal Law (Philosophical Perspective of Law). Journal of LegalRenewal , 1(2), 178. https://doi.org/10.26532/jph.v1i2.1484

ZA Amiruddin. (2004). Introduction to Legal Research Methods. Jakarta: King Grafindo Persada. 